\title{
POSSIBLE SELVES AND ACADEMIC MOTIVATION IN RUSSIAN AND AMERICAN COLLEGE STUDENTS
}

\author{
E.YU. VASILEVSKAYA, O.N. MOLCHANOVA ${ }^{\mathrm{a}}$
}

${ }^{a}$ HSE University, 20 Myasnitskaya Str., Moscow, 101000, Russian Federation

\begin{abstract}
The study presents the relationship between the positive and negative possible selves in the academic domain and academic motivation. Despite the fact that previous studies have noted the motivating potential of possible selves, the relationship between the attributes of possible selves and academic motivation has not been subjected to conscious scrutiny. The sample was formed with 361 participants, Russian (Moscow, HSE University) and American (Miami, Florida International University) college students. The Possible Selves Questionnaire and the Academic Motivation Scale were applied. It was found that Russian and American students that have a significant positive possible self in the academic domain have a higher motivation to accomplish things compared to those who do not have this image of the future. It was demonstrated that among Russian students attributes of positive possible selves (time spent thinking, actual achievement strategies, obstacles) are connected with self-development motivation. American students are characterized by interrelationships between attributes of positive possible selves (time spent thinking, perceived efficacy, outcome expectancy, importance, obstacles) and motivation to accomplish things, as well as partly other types of intrinsic and extrinsic motivation. The Russian students did not demonstrate any significant interrelationships between attributes of negative possible selves and academic motivation, while the Americans revealed the interrelationships between the outcome expectancy to avoid a negative possible self and motivation to accomplish things, as well as introjected motivation. The research results are discussed from the self-regulation perspective and in the context of socio-cultural differences.
\end{abstract}

Keywords: possible selves, self-concept, motivation, academic motivation, hopes, fears.

\section{Possible Selves}

The future has been under increasing scrutiny during the last few decades by a number of leading scholars and theorists in various fields of science, philosophy, and practice, including psychology. In psychology the problem of the future was first discussed in the studies devoted to temporal perspective and self-concept. The idea of a future image within the self-concept, in our opinion, is currently most fully represented in the concept of a possible self. Possible selves are the individual's ideas of what he or she would like to become, could become or is afraid of becoming in the future (Markus \& Nurius, 1986). Two types of possible selves can be distinguished: positive possible selves (hopes) and negative possible selves (fears). Possible selves are personally meaningful images of oneself in the future that create motivation to attain or avoid certain selves. Possible selves also influence present selves because they make individuals change their current behaviors in order to make their future images come true. 
Possible selves take part in the process of self-regulation. D. Leontiev proposed a scheme of transition of possibility into action "the possible - the valuable (meaningful) - the due - the goal - the action" (Leontiev, 2011a). In fact, it is the formula of self-regulation, where possible selves are important elements of self-regulating behavior. From D. Leontiev's point of view, self-regulation includes three functions: the function of self-determination, the function of realization, and the function of conservation (Leontiev, 2011b). Possible selves are associated with all these functions: they allow a person to self-determine in the field of opportunities and with the help of a motivating potential guide them to their realization.

Possible selves can be characterized by different attributes, for instance, actual and planned strategies to achieve a possible self, perceived efficacy, outcome expectancy, frequency of thoughts, importance, correspondence of a possible self to the real self, balance, obstacles and others (Oyserman \& Markus, 1990; Oyserman et al., 2004).

Possible selves can be related to different domains of life. For instance, K. Hooker and L. Frazier, based on the studies of H. Markus and S. Cross, suggested the following domains of possible selves: family, work, personal characteristics, physical characteristics, health, success, financial situation, leisure time, relationships, and a number of others (Cross \& Markus, 1991; Frazier \& Hooker, 2006). During different periods of life different domains of possible selves prevail; for instance, during college, possible selves related to the academic domain, personal characteristics, family, and financial situation dominate (Markus \& Nurius, 1986; Vasilevskaya, 2018). We believe that personally significant images of the future in the academic domain (which are possible selves associated with studying at university, e.g. to pass an exam, as well as further professional development in the chosen field, e.g. to find a job), are crucially important during this time period.

\section{Academic Motivation}

Academic motivation is a complex multidimensional construct that includes motives, goals, cognitive mechanisms, persistence, and coping strategies (Gordeeva, 2006).

The first studies in the field of academic motivation distinguished two types of academic motivation: extrinsic and intrinsic. Intrinsic motivation was associated with the subject's inner interest in an activity, and extrinsic motivation was connected with external reasons that prompted them to engage in an activity. At the same time, there was a tendency to consider intrinsic motives as the ones that contribute to the activity and extrinsic motives as the ones that interfere with it. In recent studies such an opposition between extrinsic and intrinsic motivation has been mitigated, it is argued that both intrinsic and extrinsic motives are important for learning.

In the theory of self-determination by E. Deci and R. Ryan it is argued that the need for autonomy is the basic human need to be an active self-determined subject, who is initiating his or her own behavior and controlling it (Deci \& Ryan, 2008). The findings in the theory of self-determination show that extrinsic motivation is represented by external regulation, introjected regulation, identified regulation 
and integrated regulation (Ryan \& Deci, 2000). A certain level of autonomy, selfregulation and proximity to intrinsic motivation characterizes each of these extrinsic motivations. External motivation is the least autonomous regulation, based on the desire to satisfy an external demand or reward contingency; introjected motivation focuses on the desire to avoid guilt or anxiety or to attain ego enhancements such as pride (Ryan \& Deci, 2000). Identified regulation is the motivation based on the conscious valuing of the goal and the acceptance of the behavior as personally important, whereas integrated motivation occurs when identified regulation is fully consistent and congruent with the self and one's needs and values. These types of extrinsic motivation are differently related to academic success, the closer the regulation to intrinsic motivation, the higher the academic achievement, the greater the involvement of the student in learning activities, and the lower the risk of dropping out of school (Connell \& Wellborn, 1991; Miserandino, 1996; Vallerand \& Bissonnette, 1992).

R. Vallerand and colleagues divide intrinsic motivation into: motivation to know, to accomplish things and to experience stimulation, and extrinsic motivation - into external, introjected, and identified regulation, while also separately defining amotivation (Vallerand et al., 1992). This theoretical model forms the basis for the Academic Motivation Scale (AMS-C 28).

In Russian psychology the problem of heterogeneity of academic motivation was discussed in the works of L. Bozhovich (Bozhovich, 1997), and at present is being developed by T. Gordeeva and her colleagues (Gordeeva et al., 2014). For T. Gordeeva motivation is more about the quality rather than the quantity, which brings her to the analysis of the motivational profiles that include both intrinsic and extrinsic motives (Gordeeva \& Sychev, 2017). T. Gordeeva, based on the ideas of the theory of self-determination and R. Vallerand's findings, suggests the following structure for academic motivation: intrinsic motivation, represented by motivation to accomplish things (sometimes also called achievement motivation), motivation to know, self-development motivation; extrinsic motivation, which includes self-esteem motivation, introjected and external regulation; and also amotivation (Gordeeva et al., 2014). This structure of academic motivation formed the basis for the Academic Motivation Scale (Gordeeva et al., 2014; Gordeeva et al., 2017).

\section{Possible Selves and Motivation}

The actualization of possible selves boosts a specific behavior, so that researchers conclude that there is a motivating potential of a possible self (Bi \& Oyserman, 2015; Cameron, 1999; Hooker \& Kaus, 1994; Markus \& Nurius, 1987; Oyserman et al., 2004; Oyserman et al., 2014). In separate empirical studies, the connection of possible selves with motivational orientations in general, regardless of a specific area of motivation, has been illustrated (Kostenko \& Grishutina, 2018).

Researchers argue if there is a connection between possible selves in the academic domain and academic motivation, as well as academic achievement. D. Oyserman showed that actualization of possible selves can be beneficial for students who don't do well in school (Oyserman et al., 2004). Some researchers think that the 
motivating potential of possible selves varies depending on different attributes of possible selves. However, there is no consent on which attributes of possible selves affect motivation, as studies demonstrated controversial results. In some works it was shown that positive possible selves had the highest motivating potential; in others it was found that the more elaborated and balanced the possible selves were, the more likely they were to affect the students' behavior (Markus \& Ruvolo, 2015); while in others it was revealed that only possible selves combined with strategies to achieve them, were predictors of academic achievement and a diligent behavior in school (Bi \& Oyserman, 2015). Confidence in one's own ability to make possible selves real also increased its motivating potential and led to the fact that students began to devote more time to their studies and had higher academic performance (Oyserman \& Destin, 2010).

Although the topic of the motivating potential of possible selves has been the basis for numerous discussions, the relationship between attributes of possible selves and academic motivation has as yet not been carefully investigated. The research of the motivating potential of possible selves in the academic domain can broaden our understanding of the process of self-determination by exploring the factors that motivate an individual to choose specific goals.

Another aspect to be considered is the cross-cultural differences in the relationship between possible selves and academic motivation (Kao, 2000). It is considered that Eastern and Western cultures fundamentally diverge: the first is dominated by collectivist priorities of interdependence (interpersonal harmony, group cohesion, social duty), while the second is dominated by individualistic priorities of independence (separate identity, personal fulfillment, autonomy) (Sedikides \& Gregg, 2002). Since the 2000s scientists have shown that the motivating potential of possible selves differs depending on the culture (Western or Eastern society) (Kao, 2000; Unemori et al., 2004). Russia is considered to be the country between the East and the West, therefore it is interesting to study the attributes of possible selves among representatives of Russian and American cultures.

The analysis of the problems raised above led us to the purpose of the present study, which is to reveal the relationship between the attributes of possible selves and academic motivation in Russian and American students.

Based on the general ideas of the theory of self-determination (Deci \& Ryan, 2000 ) and the ideas of T. Gordeeva (Gordeeva et al., 2014), we assume that 1) possible selves in the academic domain and their attributes are connected with intrinsic academic motivation and 2) there are differences in the connections between the possible selves and academic motivation for Russian and American students.

\section{Method}

\section{Sample}

361 participants took part in the study, among them 157 students of the HSE University (Russia), 115 women and $42 \mathrm{men}$, average age 18 years $(\mathrm{M}=18.20, \mathrm{SD}=$ 1.636); 204 students of the Florida International University (USA), 104 women 
and 100 men, average age 20 years $(\mathrm{M}=19.87, \mathrm{SD}=2.306)$. All participants were first year undergraduate students who had an Introduction to Psychology class.

\section{Instruments}

Methods were presented to the respondents in either Russian or English languages, depending on the country the participants lived in (Russia or the USA).

Possible Selves Questionnaire (an adaptation of the interview protocol Possible Selves, presented to Americans and Russians) (Frazier \& Hooker, 2006). The questionnaire is designed to assess respondents' desired possible selves (hopes) and not desired (fears). The Russian version is the adaptation of the American instrument, conducted with the consent of the author of the questionnaire L. Frazier.

Initially, respondents are given an explanation of what a possible self is, then they are asked to formulate all their hopes and fears. Then respondents are invited to indicate their three most important hopes and their three most important fears and describe them in detail, as well as to write actual and planned strategies to achieve or avoid possible selves and also the obstacles they might encounter. Next, for each possible self, respondents are invited to answer 5 questions on the Likert scale. These questions are aimed to identify the following attributes of possible selves: importance, correspondence of the possible self to the real self, time spent thinking, perceived efficacy, and outcome expectancy. A categorical scheme consisting of 20 domains is used to analyze the content of each possible self.

Academic Motivation Scale (presented to Russians) (Gordeeva et al., 2014). The questionnaire is designed to measure academic motivation and consists of 28 statements combined into 7 Likert scales that assess intrinsic motivation (motivation to know, to accomplish things, self-development motivation), extrinsic motivation (self-esteem motivation, introjected motivation, external motivation), and amotivation. The scale asks the question "Why do you go to college?" and items represent answers to the question, each of them associated with different types of motivation. Here are the examples: motivation to know ("I like learning", "I like learning because it is interesting"), to accomplish things ("Studies in school bring me joy, I like cracking tough problems", "I feel satisfied while cracking tough problems"), self-development motivation ("I like looking at how my competency and knowledge of different things grow", "Studies help me feel satisfied in my selfdevelopment"), self-esteem motivation ("I want to prove myself that I can do well in school", "When I do well in school I feel I'm important"), introjected motivation ("It is my duty to study and I can't avoid it", "Conscience makes me study"), external motivation ("My family will not be happy with me if I don't study well", "I don't have any other options, if I don't study I won't have a comfortable lifestyle), amotivation ("Honestly I don't know why, I think I'm just wasting time here", "I'm going to university but I'm not sure I really need it”). A higher score on each subscale indicates a greater severity of a particular motivation.

Academic Motivation Scale (AMS-C 28) (college version, presented to Americans) consists of 28 statements in the Likert scale (divided into 7 subscales) and is aimed at studying three types of intrinsic motivation (to know, to accomplish 
things, to experience stimulation), three types of extrinsic motivation (identified, introjected, external regulation), and amotivation (Vallerand et al., 1992). A higher score on each subscale indicates a greater severity of a particular regulation.

\section{Results}

The analysis of the data obtained with the Possible Selves Questionnaire was carried out using the content analysis procedure. Two experts independently from each other analyzed the entire set of the data on both the English-speaking and the Russian-speaking samples. The inter-rater reliability for the Russian-speaking sample was 0.88, and for the English-speaking sample, 0.91. In case of discrepancies in expert evaluations, these issues were discussed with a third expert until an agreement was reached.

The content analysis helped to define positive and negative possible selves related to different domains of life (family, health, academic domain, etc.). In total, 634 hopes and 596 fears from the Russian-speaking sample were collected, as well as 602 hopes and 583 fears from the English-speaking sample. As there were differences in the numbers of men and women in the Russian and American samples, we looked at the content of possible selves of Russian men and women and American men and women separately. No gender differences were found, which is why all the further analysis has been done on the whole samples.

Academic motivation was analyzed depending on the presence or absence of possible selves in the academic domain. Russian students who have a significant positive future image in the academic domain have a higher motivation to accomplish things compared to students who do not have this image as the most significant (see Table 1). In addition, students who have a significant negative future image in the academic domain have a higher external motivation compared to those who do not have this future image.

As for the American students, it was same for the Russian students, because those who have a positive future image in the academic domain have a higher motivation to accomplish things compared to those who do not have this image (see

Table 1

Academic Motivation in Connection with the Presence or Absence of a Possible Self in the Academic Domain among Russian Students

\begin{tabular}{|c|c|c|c|c|c|}
\hline & \multicolumn{2}{|r|}{ MA } & \multicolumn{2}{|r|}{ EM } \\
\hline & & $\mathrm{M}(\mathrm{SD})$ & U Mann-Whitney & $\mathrm{M}(\mathrm{SD})$ & U Mann-Whitney \\
\hline \multirow{2}{*}{ Hopes } & Presence & $16.00(3.129)$ & \multirow{2}{*}{$1803.00 *$} & $9.54(4.388)$ & \multirow{2}{*}{1937.50} \\
\hline & Absence & $14.63(3.773)$ & & $10.58(3.659)$ & \\
\hline \multirow{2}{*}{ Fears } & Presence & $14.57(3.867)$ & \multirow{2}{*}{484.50} & $14.29(5.024)$ & \multirow{2}{*}{$222.50 * *$} \\
\hline & Absence & 14.99 (3.666) & & $10.13(3.721)$ & \\
\hline
\end{tabular}

${ }^{*} p<0.01$.

Note. AM - motivation to accomplish things, IM - introjected motivation. 
Table 2). Moreover, American students who formulate their hope in the academic domain have a higher introjected motivation than those who do not.

An analysis of the relationship between the attributes of positive possible selves in the academic domain and academic motivation among Russian students was performed; the results are presented in Table 3. From all attributes of positive possible selves significant correlations were found for time spent thinking, actual achievement strategies and obstacles. There is a positive correlation between the time a Russian student thinks about their positive future image in the academic domain and their self-development motivation and self-esteem motivation. Negative correlation between the time the student spends thinking of their positive possible self and amotivation has been found. There is a positive correlation between self-development motivation and actual strategies to achieve their hope and negative correlation between the self-development motivation and obstacles the student has on the way to achieve their hope in the academic domain.

Table 2

Academic Motivation in Connection with the Presence or Absence of a Possible Self in the Academic Domain among American Students

\begin{tabular}{|c|c|c|c|c|c|}
\hline \multicolumn{2}{|c|}{} & \multicolumn{2}{c|}{ MA } & \multicolumn{2}{c|}{ IM } \\
\cline { 3 - 5 } \multicolumn{2}{|c|}{} & M (SD) & U Mann-Whitney & M (SD) & U Mann-Whitney \\
\hline \multirow{2}{*}{ Hopes } & Presence & $22.61(4.965)$ & \multirow{2}{*}{$\mathbf{1 9 3 4 . 0 0 * *}_{n n n}^{*}$} & $24.09(4.455)$ & \multirow{2}{*}{$\mathbf{1 8 9 5 . 5 0 * *}^{*}$} \\
\cline { 2 - 3 } & Absence & $20.24(6.222)$ & & $21.48(6.446)$ & \\
\hline
\end{tabular}

Table 3

The Connection of Hopes in the Academic Domain and Academic Motivation among Russian Students

\begin{tabular}{|c|c|c|c|c|c|c|c|c|}
\hline & $\mathbf{C}$ & $\mathbf{I}$ & $\mathbf{P E}$ & $\mathbf{O E}$ & $\mathbf{T}$ & AS & PS & O \\
\hline MK & 0.128 & -0.017 & 0.115 & 0.100 & 0.172 & 0.064 & -0.060 & -0.129 \\
\hline MA & 0.238 & 0.118 & 0.295 & 0.277 & 0.272 & 0.173 & -0.013 & -0.288 \\
\hline SDM & 0.211 & 0.188 & 0.189 & 0.241 & $0.398^{*}$ & $0.334^{*}$ & 0.009 & $-0.328^{*}$ \\
\hline SEM & 0.079 & 0.215 & -0.021 & 0.003 & $0.489^{* *}$ & 0.206 & 0.043 & -0.228 \\
\hline IM & -0.129 & -0.063 & -0.165 & -0.192 & 0.134 & 0.126 & -0.073 & -0.150 \\
\hline EM & -0.211 & -0.184 & -0.248 & -0.296 & -0.020 & 0.061 & -0.085 & 0.094 \\
\hline AM & -0.303 & -0.212 & -0.307 & $-0.372^{*}$ & $-0.344^{*}$ & 0.016 & 0.011 & 0.145 \\
\hline
\end{tabular}

$* p<0.05,{ }^{* *} p<0.01$.

Note. $\mathrm{C}$ - correspondence of a possible self to the real self, I - importance, PE - perceived efficacy, $\mathrm{OE}$ - outcome expectancy, T - time spent thinking, AS - actual strategies, PS - planned strategies, $\mathrm{O}$ - obstacles, MK - motivation to know, MA - motivation to accomplish things, SDM - self-development motivation, SEM - self-esteem motivation, IM - introjected motivation, EM - external motivation, AM - amotivation. 
The attributes of negative possible selves in the academic domain did not significantly correlate with academic motivation among Russian students.

As for American students, it was found that attributes of possible selves (the correspondence of a possible self to the real self, importance, perceived efficacy, outcome expectancy, time spent thinking, obstacles) are connected with academic motivation, with most of the connections shown for motivation to accomplish things (see Table 4).

An analysis of the relationship between the attributes of negative possible selves in the academic domain and academic motivation among American students revealed that such attributes of possible selves as importance, perceived efficacy, outcome expectancy, and planned strategies to avoid a fear are connected with academic motivation (see Table 5). There is a positive correlation between the outcome expectancy of avoiding a fear and motivation to accomplish things and introjected motivation. A positive correlation between the perceived efficacy of avoiding a fear and introjected motivation has been found. There is a negative correlation between the importance of a fear and motivation to experience stimulation. A negative correlation between planned strategies to avoid fears in the academic domain and amotivation has been presented.

\section{Discussion and conclusions}

In the present study both for Russian and American students more positive possible selves were collected than negative possible selves, which is consistent with the results of similar studies (Cross \& Markus, 1991; Robinson et al., 2003).

Table 4

The Connection of Hopes in the Academic Domain and Academic Motivation among American Students

\begin{tabular}{|c|c|c|c|c|c|c|c|c|}
\hline & $\mathbf{C}$ & $\mathbf{I}$ & $\mathbf{P E}$ & $\mathbf{O E}$ & $\mathbf{T}$ & AS & PS & O \\
\hline MK & $0.289^{*}$ & 0.220 & 0.207 & $0.273^{*}$ & $0.265^{*}$ & 0.016 & -0.043 & -0.163 \\
\hline MA & 0.219 & $0.294^{* *}$ & $0.313^{* *}$ & $0.384^{* *}$ & $0.245^{*}$ & -0.087 & 0.040 & $-0.322^{* *}$ \\
\hline SDM & 0.198 & 0.178 & 0.163 & $0.229^{*}$ & 0.105 & -0.065 & -0.056 & $-0.329^{* *}$ \\
\hline SEM & 0.070 & $0.310^{* *}$ & 0.215 & $0.280^{*}$ & 0.240 & 0.085 & 0.074 & $-0.359^{*}$ \\
\hline IM & -0.077 & $0.273^{*}$ & 0.092 & 0.116 & 0.182 & 0.072 & -0.072 & -0.194 \\
\hline EM & -0.144 & -0.030 & -0.058 & 0.009 & 0.092 & 0.065 & 0.057 & -0.208 \\
\hline AM & 0.078 & -0.209 & -0.029 & -0.008 & -0.040 & -0.152 & -0.014 & 0.132 \\
\hline
\end{tabular}

$* p<0.05, * * p<0.01$.

Note. $\mathrm{C}$ - correspondence of a possible self to the real self, I - importance, PE - perceived efficacy, $\mathrm{OE}$ - outcome expectancy, T - time spent thinking, AS - actual strategies, PS - planned strategies, $\mathrm{O}$ - obstacles, MK - motivation to know, MA - motivation to accomplish things, SDM - self-development motivation, SEM - self-esteem motivation, IM - introjected motivation, EM - external motivation, AM - amotivation. 
Table 5

The Connection of Fears in the Academic Domain and Academic Motivation among American Students

\begin{tabular}{|c|c|c|c|c|c|c|c|c|}
\hline & $\mathbf{C}$ & $\mathbf{I}$ & $\mathbf{P E}$ & $\mathbf{O E}$ & $\mathbf{T}$ & AS & PS & O \\
\hline MK & 0.111 & -0.164 & 0.049 & 0.134 & 0.026 & -0.177 & -0.060 & 0.178 \\
\hline MA & 0.140 & 0.114 & 0.284 & $0.351^{*}$ & -0.120 & -0.076 & 0.087 & -0.50 \\
\hline SDM & 0.191 & $-0.447^{*}$ & 0.006 & -0.064 & 0.082 & -0.155 & -0.210 & 0.068 \\
\hline SEM & -0.138 & 0.259 & 0.230 & 0.303 & -0.026 & -0.292 & -0.005 & 0.131 \\
\hline IM & 0.153 & 0.163 & $0.411^{*}$ & $0.436^{* *}$ & 0.050 & -0.180 & 0.182 & -0.148 \\
\hline EM & 0.014 & 0.145 & 0.220 & 0.157 & -0.084 & -0.235 & 0.106 & -0.296 \\
\hline AM & 0.216 & 0.065 & 0.087 & -0.092 & 0.223 & -0.084 & $-0.353^{*}$ & 0.068 \\
\hline
\end{tabular}

$* p<0.05, * * p<0.01$.

Note. C - correspondence of a possible self to the real self, I - importance, PE - perceived efficacy, $\mathrm{OE}$ - outcome expectancy, T - time spent thinking, AS - actual strategies, PS - planned strategies, $\mathrm{O}$ - obstacles, MK - motivation to know, MA - motivation to accomplish things, SDM - self-development motivation, SEM - self-esteem motivation, IM - introjected motivation, EM - external motivation, AM - amotivation.

It was found that Russian and American students who have a positive possible self in the academic domain have a higher motivation to accomplish things compared to those who do not have this possible self. It can be assumed that a personally significant positive future image, along with the motivation to accomplish things and other motivational orientations, such as persistence, goal-setting, and self-efficacy, are important for self-regulation (Gordeeva \& Osin, 2012; Leontiev, 2011a). However, it still remains unclear: does thinking about a possible self in the academic domain boost motivation to accomplish things, or, conversely, does a higher motivation to accomplish things contribute to the actualization of a future image in the academic domain? This question requires experimental verification. It was also shown that if there is a significant negative possible self in the academic domain, Russian students have a higher external motivation, and for American students, if there is a positive possible self in the academic domain, the introjected motivation is higher than if it absent. This data indirectly supports the fact that external motivation is also related to self-regulation (Ryan \& Deci, 2000).

In the present study we demonstrated the importance of a social context for the motivating potential of possible selves, which was stated in other research of attributes of possible selves (Oyserman et al., 2006). In regards to cross-cultural differences in the relationship between the attributes of possible selves and academic motivation, it was found that among Russian students such attributes of positive possible selves as time spent thinking, actual strategies, and obstacles are connected with the self-development motivation, which is the desire to develop their abilities and capacities in the academic domain. Americans have many of the attributes of positive possible selves (importance, perceived efficacy, outcome expectancy, 
time spent thinking, obstacles) associated with motivation to accomplish things; some connections are also shown for motivation to know, to experience stimulation, identified motivation, and introjected motivation. For Russian students it seems that a positive future image in the academic domain provides a better understanding of their potential, their strengths, and abilities. The positive possible self in the academic domain for Russians is not necessarily related to the desire for knowledge, achievement or desire to learn due to the fact that other people evaluate this experience as useful, which is found for Americans. It is likely that the presentation of a personally significant image of the future motivates Americans more than Russians, both for positive and negative possible selves. The low correlations of motivational orientations with the attributes of possible selves among Russians are consistent with the results of similar studies (for example, Kostenko \& Grishutina, 2018). In our opinion, in American culture greater attention is paid to the importance of individual goal-setting, and planning, including in the academic domain, e.g., students plan the trajectory of their studies at university, while in Russia students more often follow the proposed trajectory. These differences in academic paths are connected with Western and Eastern culture priorities: individualistic priorities of independence in the USA make students more involved in planning their path in university, whereas collectivist priorities of interdependence in Russia make students accept norms of the university system and think less about their own path (Sedikides \& Gregg, 2002). An alternative explanation could be that Americans are more confident about their images of the future, which is consistent with the basic American value - self-confidence (Hsyu, 2001). It could be that greater self-confidence about making future images come true creates more motivation to achieve the hopes. The analysis of reasons for a lesser consistency of the attributes of possible selves with academic motivation among Russian students, compared to Americans, undoubtedly requires a more detailed study.

In conclusion, it can be noted that the study reveals some important links between the attributes of positive and negative possible selves in the academic domain and academic motivation and also discusses cross-cultural differences. The hypotheses of the study are confirmed. The results of the present study are preliminary and require more investigation. Further research should focus on analyzing the cause-effect relationships between possible selves and motivation, a more indepth analysis of cross-cultural differences, as well as studying the relationships between possible selves in other domains (for example, interpersonal) and motivation.

\section{References}

Bi, C., \& Oyserman, D. (2015). Left behind or moving forward? Effects of possible selves and strategies to attain them among rural Chinese children. Journal of Adolescence, 44, 245-258. https://doi.org/10.1016/j.adolescence.2015.08.004

Bozhovich, L. I. (1997). Otnoshenie shkol'nikov k ucheniyu kak psihologicheskaya problema [The attitude of school students to learning as a psychological problem]. In D. I. Feldshtein (Ed.), 
Problemy formirovaniya lichnosti [Problems of personality formation] (pp. 55-91). Moscow: Institut prakticheskoi psikhologii; Voronezh: NPO "MODEK".

Cameron, J. E. (1999). Social identity and the pursuit of possible selves: Implications for the psychological well-being of university students. Group Dynamics: Theory, Research, and Practice, 3(3), 179-189. https://doi.org/10.1037/1089-2699.3.3.179

Connell, J. P., \& Wellborn, J. G. (1991). Competence, autonomy and relatedness: A motivational analysis of self-system processes. In M. R. Gunnar \& L. A. Sroufe (Eds.), The Minnesota Symposia on Child Psychology (Vol. 23, pp. 43-77). Hillsdale, NJ: Lawrence Erlbaum Associates, Inc.

Cross, S., \& Markus, H. (1991). Possible selves across the lifespan. Human Development, 34, 230-255. https://doi.org/10.1159/000277058

Deci, E. L., \& Ryan, R. M. (2008). Self-determination theory: A macrotheory of human motivation, development, and health. Canadian Psychology/Psychologie canadienne, 49(3), 182-185. https://doi.org/10.1037/a0012801

Frazier, L. D., \& Hooker, K. (2006). Possible selves in adult development: Linking theory and research. In C. Dunkel \& J. Kerpelman (Eds.), Possible selves: Theory, research, and application (pp. 41-59). Huntington, NY: Nova Science Publishers.

Gordeeva, T. O. (2006). Psihologiya motivatsii dostizheniya [Psychology of achievement motivation]. Moscow: Smysl.

Gordeeva, T. O., \& Osin, E. N. (2012). Differences in achievement motivation and learning motivation in students exhibiting different types of academic attainment (Unified State Examination (USE) scores, academic competition results, academic records). Psikhologicheskie Issledovaniya, 5(24), 4. http://psystudy.ru (in Russian)

Gordeeva, T. O., \& Sychev, O. A. (2017). Motivational profiles as predictors of students' self-regulation and academic achievement. Moscow University Psychology Bulletin, 1, 67-87. https://doi.org/10.11621/vsp.2017.01.69 (in Russian)

Gordeeva, T. O., Sychev, O. A., Gizhitsky, V. V., \& Gavrichenkova, T. K. (2017). Intrinsic and Extrinsic Academic Motivation Scale for schoolchildren. Psikhologicheskaya Nauka i Obrazovanie [Psychological Science and Education], 22(2), 65-74. https://doi.org/10.17759/pse.2017220206 (in Russian)

Gordeeva, T. O., Sychev, O. A., \& Osin, E. N. (2014). "Academic Motivation Scales" Questionnaire. Psikhologicheskii Zhurnal, 35(4), 98-109. (in Russian)

Hooker, K., \& Kaus, C. R. (1994). Health-related possible selves in young and middle adulthood. Psychology and Aging, 9(1), 126-133. https://doi.org/10.1037/0882-7974.9.1.126

Hsyu, F. (2001). Bazovye amerikanskie tsennosti i nacional'niy harakter [Basic American values and national traits]. In A. A. Belik (Ed.), Lichnost', kul'tura, etnos: sozremennaya psihologicheskaya antropologiya [Personality, culture, ethnos: modern psychological anthropology] (pp. 407-430). Moscow: Smysl

Kao, G. (2000). Group images and possible selves among adolescents: Linking stereotypes to expectations by race and ethnicity. Sociological Forum, 15(3), 407-430. https://doi.org/10.1023/A:1007572209544

Kostenko, V. Yu., \& Grishutina, M. M. (2018). Impossible self: preliminary research in the context of the theory of Hazel Marcus. Penzenskii Psikhologicheskii Vestnik, 1(10), 126-148. https://doi.org/10.17689/psy-2018.1.8 (in Russian)

Leontiev, D. A. (2011a). Novye orientiry ponimaniya lichnosti v psihologii: ot neobhodimogo k vozmozhnomu [New orientations in understanding personality in psychology: from necessity to possibility]. In D. A. Leontiev (Ed.), Lichnostnyi potentsial: struktura i diagnostika [Personality potential: structure and assessment] (pp. 12-41). Moscow: Smysl. 
Leontiev, D. A. (2011b). Lichnostnyi potentsial kak potentsial samoreguliatsii [Personality potential as the potential of self-regulation]. In D. A. Leontiev (Ed.), Lichnostnyi potentsial: struktura i diagnostika [Personality potential: structure and assessment] (pp. 107-130). Moscow: Smysl.

Markus, H., \& Nurius, P. (1986). Possible selves. American Psychologist, 41(9), 954-969. https://doi.org/10.1037/0003-066X.41.9.954

Markus, H., \& Nurius, P. (1987). Possible selves: The interface between motivation and the self-concept. In K. Yardley \& T. Honess (Eds.), Self and identity: Psychosocial perspectives (pp. 157-172). Oxford, England: Wiley \& Sons.

Markus, H., \& Ruvolo, A. (2015). Possible selves: Personalized representations of goals. In L. A. Pervin (Ed.), Goal concepts in personality and social psychology (pp. 211-241). Psychology Press.

Miserandino, M. (1996). Children who do well in school: Individual differences in perceived competence and autonomy in above-average children. Journal of Educational Psychology, 88(2), 203-214. https://doi.org/10.1037/0022-0663.88.2.203

Oyserman, D., Bybee D., \& Terry, K. (2006). Possible selves and academic outcomes: How and when possible selves impel action. Journal of Personality and Social Psychology, 91(1), 188-204. https://doi.org/10.1037/0022-3514.91.1.188

Oyserman, D., Bybee, D., Terry, K., \& Hart-Jonson, T. (2004). Possible selves as roadmaps. Journal of Research in Personality, 38(2), 130-149. https://doi.org/10.1016/S0092-6566(03)00057-6

Oyserman, D., \& Destin, M. (2010). Identity-based motivation: Implications for intervention. The Counseling Psychologist, 38(7), 1001-1043. https://doi.org/10.1177/0011000010374775

Oyserman, D., Destin, M., \& Novin, S. (2014). The context-sensitive future self: Possible selves motivate in context, not otherwise. Self and Identity, 14(2), 173-188. https://doi.org/10.1080/15298868.2014.965733

Oyserman, D., \& Markus, H. (1990). Possible selves and delinquency.Journal of Personality and Social Psychology, 59(1), 112-125. https://doi.org/10.1037/0022-3514.59.1.112

Robinson, B. S., Davis, K. L., \& Meara, N. M. (2003). Motivational attributes of occupational possible selves for low-income rural women. Journal of Counseling Psychology, 50(2), 156-164. https://doi.org/10.1037/0022-0167.50.2.156

Ryan, R. M., \& Deci, E. L. (2000). Self-determination theory and the facilitation of intrinsic motivation, social development, and well-being. American Psychologist, 55(1), 68-78. https://doi.org/10.1037//0003-066X.55.1.68

Sedikides, K., \& Gregg, A. (2002). Portraits of self. In M.A. Hogg \& J. Cooper (Eds.), Sage handbook of social psychology (pp. 110-138). Sage Publications.

Unemori, P., Omoregie, H., \& Markus, H. (2004). Self-portraits: Possible selves in EuropeanAmerican, Chilean, Japanese and Japanese-American cultural contexts. Self and Identity, 3(4), 321-338. https://doi.org/10.1080/13576500444000100

Vallerand, R. J., \& Bissonnette, R. (1992). Intrinsic, extrinsic, and amotivational styles as predictors of behavior: A prospective study. Journal of Personality, 60(3), 599-620. https://doi.org/10.1111/j.1467-6494.1992.tb00922.x

Vallerand, R. J., Pelletier, L. G., Blais, M. R., Briere, N. M., Senecal, C., \& Vallieres, E. F. (1992). The Academic Motivation Scale: A measure of intrinsic, extrinsic and amotivation in education. Educational and Psychological Measurement, 52(4), 1003-1017. https://doi.org/10.1177/0013164492052004025

Vasilevskaya, E. Yu. (2018). Comparative analysis of professional possible selves among Russian and American students. Organizacionnaya psihologiya [Organizational Psychology], 8(4), 95-110. 
Ekaterina Yu. Vasilevskaya - PhD in Psychology.

Research Area: possible selves, self-concept, motivation, motivating potential.

Email: ek.vasilevskaya@gmail.com

Olga N. Molchanova - Professor, Department of Psychology, HSE University, PhD in Psychology, Associate Professor.

Research Area: self-concept, self-esteem, developmental psychology.

Email: omolchanova@hse.ru 


\title{
Возможные «Я» и академическая мотивация у российских и американских студентов университета
}

\author{
Е.Ю. Василевская, О.Н. Молчанова ${ }^{a}$
}

${ }^{a}$ HSE University, 20 Myasnitskaya Str., Moscow, 101000, Russian Federation

\section{Резюме}

В исследовании представлен анализ взаимосвязи позитивных и негативных возможных «Я» в академической сфере с академической мотивацией. Несмотря на то что в предыдущих исследованиях отмечалась мотивирующая и направляющая поведение функция возможных «Я», детально связь параметров возможных «Я» и академической мотивации не была изучена. Выборку исследования составил 361 человек, российские (Москва, НИУ ВШЭ) и американские (Майами, Международный университет Флориды) студенты университетов. В качестве методического инструментария использовались Методика «Возможные “Я” и Шкала академической мотивации. Результаты исследования показали, что российские и американские студенты, которые имеют значимое позитивное возможное «Я» в академической сфере, имеют выше мотивацию достижения по сравнению с теми, кто не имеет данного значимого образа будущего. Выявлено, что у российских студентов такие параметры позитивных возможных «Я», как время, уделяемое размышлениям, актуальные стратегии достижения, препятствия, связаны с мотивацией саморазвития. У американских студентов наблюдаются взаимосвязи параметров позитивных возможных «Я» (время, уделяемое размышлениям, воспринимаемая эффективность, ожидаемый результат, важность, препятствия) с мотивацией достижения, а также частично с другими типами внутренней и внешней мотивации. Российские студенты не обнаружили значимых взаимосвязей между параметрами негативных возможных «Я» и академической мотивацией, у американцев отмечены взаимосвязи ожидаемого результата избегания негативного возможного «Я» с мотивацией достижения и интроецированной мотивацией. Результаты исследования обсуждаются с позиции общих представлений о саморегуляции и в контексте кросс-культурных различий.

Ключевые слова: возможные «Я», Я-концепция, мотивация, академическая мотивация, надежды, опасения.

Василевская Екатерина Юрьевна - кандидат психологических наук.

Сфера научных интересов: возможные «Я», Я-концепция, мотивация, мотивационный потенциал.

Контакты: ek.vasilevskaya@gmail.com

Молчанова Ольга Николаевна - профессор, департамент психологии, Национальный исследовательский университет «Высшая школа экономики», кандидат психологических наук, доцент.

Сфера научных интересов: Я-концепция, самооценка, психология развития.

Контакты: omolchanova@hse.ru 